\title{
PENGARUH EMPOWERING LEADERSHIP TERHADAP KINERJA GURU DENGAN PSYCHOLOGICAL EMPOWERMENT SEBAGAI VARIABEL MEDIASI
}

\author{
Yustita Damayanti \\ Universitas Negeri Surabaya \\ yusstyita@gmail.com
}

\begin{abstract}
This study aims to determine the effect of empowering leadership on teachers performance with psychological empowerment as a mediating variable. Research object at SMPN 1 Pacitan and SMPN 2 Pacitan. This study uses quantitative methods with a population of 101 teachers and uses a simple random sampling technique with 81 respondents. Data analysis used Structural Equation Modeling (SEM) with analysis method, namely Partial Least Square (PLS). Data processing used Smart PLS 3.0 software. The results of this study conclude that empowering leadership has a significant positive effect on teachers performance, empowering leadership has a significant positive effect on psychological empowerment, psychological empowerment has a significant positive effect on teachers performance, and psychological empowerment as a mediating variable affects the relationship between empowering leadership and teachers performance. Principals must increase the effectiveness of empowering leadership by applying high work discipline so that the psychological empowerment of teachers will also increase and have a good impact on the teacher's performance. Local government support in the provision of learning support infrastructure also needs to be improved, thus making it easier for teachers to improve the quality of teaching to students.
\end{abstract}

Keywords: empowering leadership; psychological empowerment; teachers performance.

\section{PENDAHULUAN}

Pendidikan merupakan bagian utama pembangunan suatu bangsa (Supratikto et al., 2014). Menurut Sampurno \& Wibowo (2015), pendidikan berperan penting dalam mengembangkan sumber daya manusia. Pendidikan adalah usaha mewujudkan proses pembelajaran secara aktif untuk mengembangkan potensi peserta didik agar memiliki kepribadian, kecerdasan, dan keterampilan yang berguna bagi diri, lingkungan, bangsa, dan negara (Hartanto \& Purwanto, 2019). Guru menjadi salah satu faktor penentu untuk meningkatkan kualitas pendidikan (Yusoff et al., 2014). Guru adalah tenaga profesional yang memiliki kewajiban merencanakan dan melakukan proses pembelajaran, menilai hasil pembelajaran, melaksanakan pembimbingan, dan pelatihan, serta berkomitmen untuk meningkatkan mutu pendidikan (Undang-Undang Republik Indonesia Nomor 20 Tahun 2003 tentang Sistem Pendidikan Nasional, 2003).

Standar kompetensi guru ditetapkan pemerintah guna menjaga kinerja guru tetap baik. Kinerja adalah perilaku nyata yang ditampilkan seorang pegawai sesuai dengan perannya dalam organisasi (Muliawan et al., 2017). Anggota organisasi tidak dapat bekerja optimal tanpa otonomi atas pekerjaan mereka (Spreitzer, 1995). Dalam konteks ini, empowering leadership menjadi variabel penting yang secara proaktif dapat memajukan perubahan sekolah dengan memerbolehkan penyampaian ide-ide konstruktif dari sisi tenaga pendidik. Empowering leadership merupakan suatu proses pelaksanaan berbagi kekuasaan dengan bawahan menyesuaikan kemampuan, menghindari kendala dalam mencapai kinerja, dan memberikan otonomi lebih besar dalam pengambilan keputusan (Zhang \& Bartol, 2010).

Beberapa penelitian terdahulu membuktikan adanya pengaruh empowering leadership terhadap kinerja guru (Ali et al., 2018; Gahlawat et al., 2019). Namun, Humborstad et al. (2014) menyatakan hubungan antara empowering leadership dan work performance tidak konsisten satu sama lain bahkan cenderung negatif.

Saat ini, tanggungjawab pemimpin tidak hanya memberikan otonomi kepada bawahan, tetapi juga harus memeriksa apakah bawahan merasa berdaya secara psikologis atau tidak (Zhang \& Bartol, 
Yustita Damayanti. Pengaruh Empowering Leadership terhadap Kinerja Guru dengan Psychological Empowerment sebagai Variabel Mediasi.

2010). Spreitzer (1995) mendefinisikan psychological empowerment sebagai sebuah keadaan psikologis yang diwujudkan dalam empat kognisi yakni, meaning, competence, self-determination, dan impact. Psychological empowerment dipandang sebagai penentu proses peningkatan inisiasi tugas dan ketekunan karyawan.

Penelitian yang berkaitan dengan pengaruh empowering leadership terhadap psychological empowerment telah dilakukan sebelumnya (Amundsen \& Martinsen, 2015; Rayan et al., 2019; Zhang \& Bartol, 2010). Namun, Knezovic, \& Musrati (2018) mengemukakan hasil yang kontras yakni tidak menemukan adanya pengaruh signifikan antara empowering leadership dengan psychological empowerment.

Menurut Adriansyah \& Suryani (2018), psychological empowerment berpengaruh positif terhadap kinerja pegawai. Psychological empowerment menghasilkan kemandirian dan motivasi intrinsik pada pegawai yang akan memberi dampak positif pada kinerja mereka (Cetin \& Askun, 2018). Spreitzer (1995) menyatakan pegawai merasa termotivasi untuk melaksanakan pekerjaan dengan lebih baik ketika mereka memiliki kemampuan yang diperlukan untuk melakukan tugas pekerjaan mereka.

Beberapa penelitian terdahulu yang mendukung pengaruh signifikan positif variabel psychological empowerment terhadap kinerja guru (Gahlawat et al., 2019; Yilmaz, 2015). Tetapi, Chasanah (2008) mengemukakan hasil penelitian yang berbeda yakni, tidak terdapat pengaruh positif antara empowerment dengan kinerja pegawai.

Kim \& Beehr (2018) menunjukkan empowering leadership memengaruhi hasil kinerja melalui mekanisme psikologis yang berbeda. Sejalan dengan hal itu, Gahlawat et al. (2019) mengemukakan psychological empowerment memediasi dampak empowering leadership terhadap job performance. Ketika kepala sekolah menerapkan perilaku pemberdayaan, guru akan mengalami psychological empowerment yang tinggi dan pada gilirannya akan meningkatkan job performance mereka.

Lokasi penelitian ini adalah SMP Negeri 1 Pacitan dan SMP Negeri 2 Pacitan. Sesuai dengan rerata hasil ujian nasional SMPN di Kecamatan Pacitan periode 2014/2015-2018/2019 yang diterbitkan oleh Pusat Penelitian Pendidikan Kementerian Pendidikan dan Kebudayaan di Tabel 1. Kedua sekolah tersebut merupakan peraih rerata hasil ujian nasional tertinggi di Kecamatan Pacitan.

\section{Tabel 1. \\ RERATA HASIL UJIAN NASIONAL SMPN DI KECAMATAN PACITAN PERIODE 2014/2015-2018/2019}

\begin{tabular}{lcccccc}
\hline \multicolumn{1}{c}{ Nama Sekolah } & $\mathbf{2 0 1 4 / 2 0 1 5}$ & $\mathbf{2 0 1 5 / 2 0 1 6}$ & $\mathbf{2 0 1 6 / 2 0 1 7}$ & $\mathbf{2 0 1 7 / 2 0 1 8}$ & $\mathbf{2 0 1 8} / \mathbf{2 0 1 9}$ & Mean \\
\hline SMPN 1 Pacitan & 84,31 & 82,50 & 75,68 & 75,64 & 77,03 & 79,03 \\
SMPN 2 Pacitan & 76,65 & 70,33 & 63,28 & 59,33 & 61,04 & 66,13 \\
SMPN 3 Pacitan & 59,97 & 60,48 & 47,37 & 49,32 & 47,26 & 52,88 \\
SMPN 4 Pacitan & 65,69 & 70,15 & 51,07 & 52,67 & 52,37 & 58,39 \\
SMPN 5 Pacitan Satu Atap & 52,97 & 47,54 & 47,53 & 47,71 & 47,40 & 48,63 \\
\hline
\end{tabular}

Sumber: Pusat Penelitian Pendidikan Kementerian Pendidikan dan Kebudayaan (2021, data diolah)

Sampurno \& Wibowo (2015) mengemukakan ketercapaian hasil prestasi belajar siswa terjadi karena adanya peran strategis guru secara sinergis dan bertanggung jawab dalam melaksanakan proses pendidikan. Penguasaan kompetensi guru menjadi penentu ketercapaian kualitas pembimbingan siswa (Hartanto \& Purwanto, 2019). Dari hasil wawancara dengan beberapa guru, selama ini kepala sekolah memberikan kesempatan bagi semua guru untuk menyelesaikan tugas pekerjaannya sesuai dengan kemampuan individu. Kepala sekolah memberikan kepercayaan kepada guru untuk menggunakan model pembelajaran sesuai dengan kreativitas mereka dalam proses pembelajaran. Kesempatan yang diberikan kepala sekolah tersebut dimanfaatkan dengan baik oleh guru. Mereka memiliki psychological empowerment dan keyakinan terhadap kemampuan dalam melaksanakan pekerjaan. Setiap tahun pelajaran dilaksanakan penilaian kinerja guru untuk pembinaan karir, kepangkatan dan 
jabatan. Dengan adanya penilaian ini, guru dapat mengetahui sejauh mana kemampuan dan kompetensi yang dimilikinya dalam proses pembelajaran.

Penelitian ini bertujuan untuk mengetahui pengaruh empowering leadership terhadap kinerja guru dengan psychological empowerment sebagai variabel mediasi.

\section{KAJIAN PUSTAKA DAN PENGEMBANGAN HIPOTESIS}

\section{Empowering Leadership}

Empowering leadership merupakan upaya memotivasi seorang karyawan secara intrinsik dengan berbagi kekuasaan dan dukungan untuk pengembangan karyawan (Amundsen \& Martinsen, 2015). Empowering leadership lebih dari sekedar memengaruhi orang lain, tetapi menyerahkan kekuasaan dari pemimpin kepada pegawai (Rayan et al., 2019). Empowering leadership memberikan kesempatan kepada bawahan untuk menghargai diri dan kemampuannya (Pearce \& Sims, 2002). Pemimpin memberikan keyakinan kepada karyawan bahwa mereka mampu menghasilkan metode dan ide-ide baru berkaitan dengan pekerjaan mereka (Rochani \& Wijayati, 2020).

Albrecht \& Andreetta (2011) mendefinisikan empowering leadership sebagai usaha memberdayakan karyawan dengan memberikan otonomi, kebijaksanaan, kontrol dan lintang keputusan kepada karyawan. Pemimpin mendorong partisipasi dalam pengambilan keputusan, dengan melibatkan pegawai dalam pembuatan keputusan tersebut (Arnold et al., 2000). Peningkatan kebermaknaan pekerjaan dilaksanakan dengan memperluas tanggung jawab pekerjaan kepada karyawan (Atik \& Celik, 2020). Karyawan diharapkan merasa diberdayakan sehingga akan meningkatkan keterlibatan dan komitmen karyawan (Park \& Hassan, 2018). Sejalan dengan itu, Srivastava et al. (2006) mengartikan empowering leadership sebagai gaya kepemimpinan desentralisasi kekuasaan dengan memberikan tanggungjawab dan otonomi kepada karyawan.

\section{Psychological Empowerment}

Spreitzer (1995) mendefinisikan psychological empowerment sebagai keadaan psikologis yang diwujudkan dalam empat kognisi: meaning, competence, self-determination dan impact. Psychological empowerment adalah proses peningkatan pemahaman self-efficacy karyawan melalui identifikasi kondisi yang terjadi selama bekerja dalam organisasi (Zhang \& Bartol, 2010). Psychological empowerment berkaitan dengan kesejahteraan karyawan, dimana karyawan merasa diberdayakan dan tidak merasa tertekan dengan tuntutan pekerjaan sehingga dapat berinovasi dan meningkatkan kemampuan (Wardani \& Amaliah, 2020). Psychological empowerment berpotensi memberi karyawan perasaan lebih besar atas kontrol dalam pekerjaan (Kazlauskaite et al., 2011). Karyawan akan merasa bahwa perilakunya dapat membuat perbedaan terhadap hasil kerja (Zhu et al., 2019).

Menurut Tanriverdi et al. (2019), psychological empowerment merupakan motivasi internal dalam diri karyawan yang mencerminkan orientasi karyawan terhadap peran mereka dalam pekerjaan. Psychological empowerment mengarah pada peningkatan kinerja (Hameed \& Waheed, 2015). Psychological empowerment dapat meningkatkan kompetensi dan memberi kesempatan kepada karyawan untuk mandiri, yang akan berdampak pada lingkungan kerja, kondisi kerja dan layanan yang disediakan (Özaralli, 2015).

\section{Kinerja Guru}

Marliani (2015) mengungkapkan kinerja sebagai hasil yang diperoleh dari pekerjaan. Kinerja didefinisikan sebagai total nilai yang diharapkan organisasi terhadap perilaku individu selama periode waktu tertentu (Welbourne et al., 1997). Kinerja merupakan tingkat pelaksanaan tugas yang dapat dicapai oleh seseorang, unit atau divisi dengan menggunakan kemampuan yang ada untuk mencapai tujuan organisasi (Humborstad et al., 2014). Kesuksesan suatu organisasi tergantung pada kinerja yang baik dari karyawannya (Ali et al., 2018). 
Yustita Damayanti. Pengaruh Empowering Leadership terhadap Kinerja Guru dengan Psychological Empowerment sebagai Variabel Mediasi.

Kinerja tidak hanya berkaitan dengan kegiatan inti (task performance), tetapi juga kegiatan lain (contextual performance) dalam rangka memahami konsep kinerja secara holistik (Aguinis, 2007). Kegiatan inti berkaitan dengan pekerjaan prosedural dan tugas teknis yang membutuhkan pengetahuan, kemampuan dan pengalaman, sedangkan kegiatan kontekstual berkaitan dengan faktorfaktor seperti moralitas, dedikasi pekerjaan dan kerjasama (Campbell \& Hwa, 2014). Task performance dan contextual performance yang dilaksanakan dengan baik oleh karyawan akan mempermudah pencapaian tujuan organisasi (Goodman \& Svyantek, 1999). Seperti sektor lainnya, sektor pendidikan juga tergantung pada kinerja yang baik dari karyawannya, karena kualitas pendidikan dipengaruhi oleh kinerja guru. Oleh karena itu, kinerja yang efektif dari seorang guru sangat penting untuk peningkatan sistem pendidikan secara keseluruhan (Yusoff et al., 2014).

\section{Hubungan antar Variabel}

Hubungan antar variabel dapat diamati dalam gambar 1 kerangka konseptual.

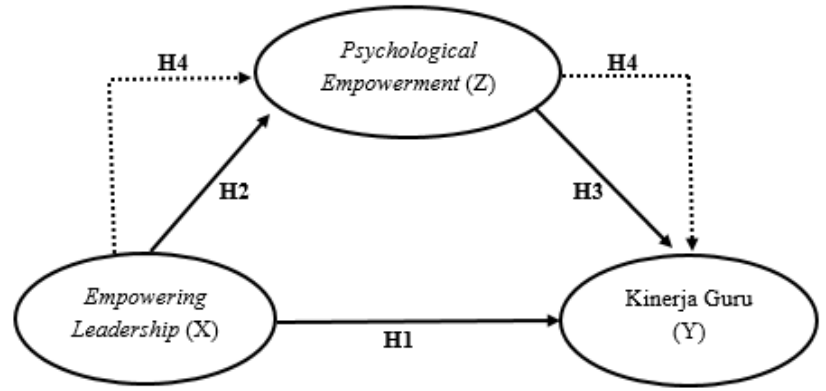

\section{Gambar 1. KERANGKA KONSEPTUAL}

Kinerja guru berkaitan erat dengan empowering leadership. Menurut Ahearne et al. (2005), konseptualisasi pemberdayaan melibatkan kepemimpinan, menyoroti pentingnya pekerjaan, memberikan partisipasi dalam pengambilan keputusan dan menyampaikan keyakinan bahwa kinerja akan semakin baik. Empowering leadership sebagai proses yang memungkinkan berbagi kekuasaan antara kepala sekolah dengan guru. Melibatkan guru dalam proses pengambilan keputusan tentang proses belajar (Atik \& Celik, 2020). Menyediakan otonomi yang lebih besar, memberikan kepercayaan kepada kemampuan guru, memfasilitasi dengan berbagai pelatihan, pembinaan dan dorongan emosional. Melalui tindakan ini, pegawai akan menyadari tujuan dan makna pekerjaan mereka (Fong \& Snape, 2015). Pegawai mampu memimpin diri sendiri untuk meningkatkan partisipasi dalam pekerjaan, sehingga dapat tercapai kinerja yang baik (Pearce \& Sims, 2002). Beberapa penelitian menunjukkan bahwa empowering leadership mempunyai pengaruh signifikan positif terhadap performance (Ali et al., 2018; Sudibjo \& Widiastuti, 2021; Zhang \& Gheibi, 2015).

\section{H1: Empowering leadership berpengaruh signifikan positif terhadap kinerja guru.}

Fokus utama empowering leadership terletak pada psychological empowerment yaitu apakah secara psikologis pegawai mendapatkan kekuasaan atas pekerjaan mereka (Spreitzer, 1995). Pegawai yang dilibatkan dalam pengambilan keputusan dan otonominya didukung akan merasa lebih kuat secara psikologis (Atik \& Celik, 2020). Pemimpin yang memberdayakan adalah panutan, pelatih dan fasilitator (Raub \& Robbert, 2010). Empowering leadership berinteraksi secara signifikan dengan psychological empowerment untuk memengaruhi kreativitas pegawai. Tingkat empowering leadership yang tinggi ditambah dengan tingkat psychological empowerment yang tinggi pula akan menyebabkan tingkat kreativitas meningkat (Özaralli, 2015). Chen et al. (2011) dan Thomas \& Rahschulte (2018) menyatakan empowering leadership memiliki dampak langsung yang positif terhadap psychological empowerment.

H2: Empowering leadership berpengaruh signifikan positif terhadap psychological empowerment. 
Menurut Spreitzer (1995), pegawai termotivasi melaksanakan pekerjaan dengan baik ketika mereka merasa memiliki kemampuan yang diperlukan dalam melaksanakan tugas pekerjaan. Saat pegawai memahami makna pekerjaan dan mengerti bahwa dengan menyelesaikan pekerjaan akan berdampak baik terhadap rekan kerja di organisasi, mereka akan berupaya menghasilkan kinerja yang baik (Liden et al., 2000). Psychological empowerment menghasilkan self-efficacy dan intrinsic motivation yang berdampak positif pada kinerja (Cetin \& Askun, 2018). Menurut Hameed \& Waheed (2015), psychological empowerment berpengaruh signifikan terhadap performance. Sejalan dengan hal itu, Adriansyah \& Suryani (2018) menemukan psychological empowerment berpengaruh positif terhadap kinerja karyawan. Apabila karyawan merasakan kenyamanan terhadap pekerjaannya, mereka akan menyadari arti penting sebuah pekerjaan, sehingga mereka akan menghasilkan kinerja yang lebih baik.

\section{H3: Psychological empowerment berpengaruh signifikan positif terhadap kinerja guru.}

Kim \& Beehr (2018) menunjukkan empowering leadership memengaruhi hasil kinerja melalui mekanisme psikologis yang berbeda. Empowering leadership dipandang sebagai proses berbagi kekuasaan antara pemimpin dengan pegawai, di mana pegawai dapat mengatur diri sendiri untuk mencapai kognisi psikologis dan kinerja yang lebih tinggi (Kasemsap, 2013). Özaralli (2015) mengungkapkan bahwa psychological empowerment memoderasi hubungan antara empowering leadership dengan kreativitas pegawai yang merupakan prediktor signifikan dari kinerja pegawai. Gahlawat et al. (2019) dan Wallace et al. (2011) menemukan bahwa psychological empowerment memediasi dampak empowering leadership terhadap performance. Ketika pemimpin menerapkan perilaku pemberdayaan, maka pegawai akan mengalami psychological empowerment yang tinggi dan pada gilirannya akan meningkatkan job performance mereka.

H4: Empowering leadership berpengaruh terhadap kinerja guru yang dimediasi oleh psychological empowerment.

\section{METODE PENELITIAN}

Penelitian ini menggunakan metode kuantitatif. Pengumpulan data dilaksanakan dengan observasi, wawancara, penyebaran kuesioner secara online dan penelusuran informasi yang dipublikasikan oleh sekolah. Skala Likert 1-5 merupakan metode perhitungan yang digunakan dalam penelitian ini. Lokasi penelitian yaitu SMP Negeri 1 Pacitan dan SMP Negeri 2 Pacitan. SMP Negeri 1 Pacitan beralamat di Jl. A. Yani No. 41 Pacitan, Jawa Timur (63511). SMP Negeri 2 Pacitan beralamat di Jl. A. Yani No. 31 Pacitan, Jawa Timur (63511). Populasi penelitian berjumlah 58 guru SMP Negeri 1 Pacitan dan 43 guru SMP Negeri 2 Pacitan. Simple random sampling adalah teknik pengambilan sampel yang digunakan dalam penelitian ini. Pemilihan jumlah sampel menggunakan rumus Slovin dengan jumlah responden sebanyak 81 guru SMP Negeri di Kecamatan Pacitan. Analisis data menggunakan Structural Equation Modeling (SEM) dengan analysis method yaitu Partial Least Square (PLS). Pengolahan data menggunakan software SmartPLS 3.0.

Pengukuran empowering leadership merujuk pada indikator Ahearne et al. (2005), yaitu: enhancing the meaningfulness of work, fostering participation in decision making, expressing confidance in high performance dan providing autonomy from bureaucratic constraints. Pengukuran psychological empowerment menggunakan indikator yang merujuk pada Spreitzer (1995), yakni: meaning, competence, self-determination dan impact. Pengukuran kinerja guru menggunakan indikator dari Goodman \& Svyantek (1999), yaitu: altruism, conscientiousness dan task performance.

\section{HASIL DAN PEMBAHASAN}

Tabulasi data sesuai karakteristik sampel dilakukan setelah diperoleh hasil penyebaran kuesioner. Kuesioner yang dikembalikan oleh responden sejumlah 81 kuesioner. Dari jumlah sampel keseluruhan yaitu 81 responden, laki-laki berjumlah 28 guru $(34,6 \%)$ dan perempuan berjumlah 53 guru $(65,4 \%)$. Guru berusia $<30$ tahun berjumlah 2 guru $(2,5 \%)$, sementara itu yang berusia antara $30-$ 
Yustita Damayanti. Pengaruh Empowering Leadership terhadap Kinerja Guru dengan Psychological Empowerment sebagai Variabel Mediasi.

40 tahun berjumlah 15 guru (18,5\%), usia antara 41-51 tahun berjumlah 12 guru (14,8\%), dan yang berusia $>50$ tahun berjumlah 52 guru $(64,2 \%)$. Guru dengan jenjang pendidikan SMP berjumlah 1 guru $(1,2 \%)$, guru dengan jenjang pendidikan SMA/SMK berjumlah 2 guru $(2,5 \%)$, guru dengan jenjang pendidikan S1 berjumlah 66 guru $(81,5 \%)$ dan guru dengan jenjang pendidikan S2 berjumlah 12 guru (14,8\%). Ditinjau dari masa kerja, guru dengan masa kerja selama $<5$ tahun berjumlah 15 guru $(18,5 \%)$, guru yang telah bekerja selama rentang waktu antara 5-10 tahun berjumlah 2 guru $(2,5 \%)$, guru yang bekerja selama rentang waktu antara 11-15 tahun berjumlah 5 guru $(6,2 \%)$, dan guru yang telah bekerja selama rentang waktu antara 16-20 tahun berjumlah 14 guru $(17,3 \%)$, serta guru yang telah bekerja selama $>20$ tahun berjumlah 45 guru $(55,6 \%)$.

Penilaian mean jawaban responden pada penelitian ini angka paling rendah adalah 1 dan paling tinggi adalah 5. Adapun penjelasannya, mean penilaian indikator variabel empowering leadership yaitu sebesar 3,89 untuk enhancing the meaningfulness of work, sebesar 3,76 untuk fostering participation in decision making, sebesar 3,78 untuk expressing confidance in high performance dan sebesar 3,62 untuk providing autonomy from bureaucratic constraints, dengan mean variabel sebesar 3,76 yang tergolong dalam kategori baik. Adapun indikator variabel psychological empowerment memiliki nilai mean sebanyak 3,73 untuk meaning, sebanyak 3,85 untuk competence, sebanyak 3,90 untuk selfdetermination, dan sebanyak 3,72 untuk impact dengan mean variabel sebanyak 3,80 yang tergolong kategori baik. Selanjutnya, nilai mean indikator dari kinerja guru sebesar 3,75 untuk altruism, sebesar 3,52 untuk conscientiousness, dan sebesar 3,54 untuk task performance, dengan mean variabel sebesar 3,60 yang tergolong dalam kategori baik.

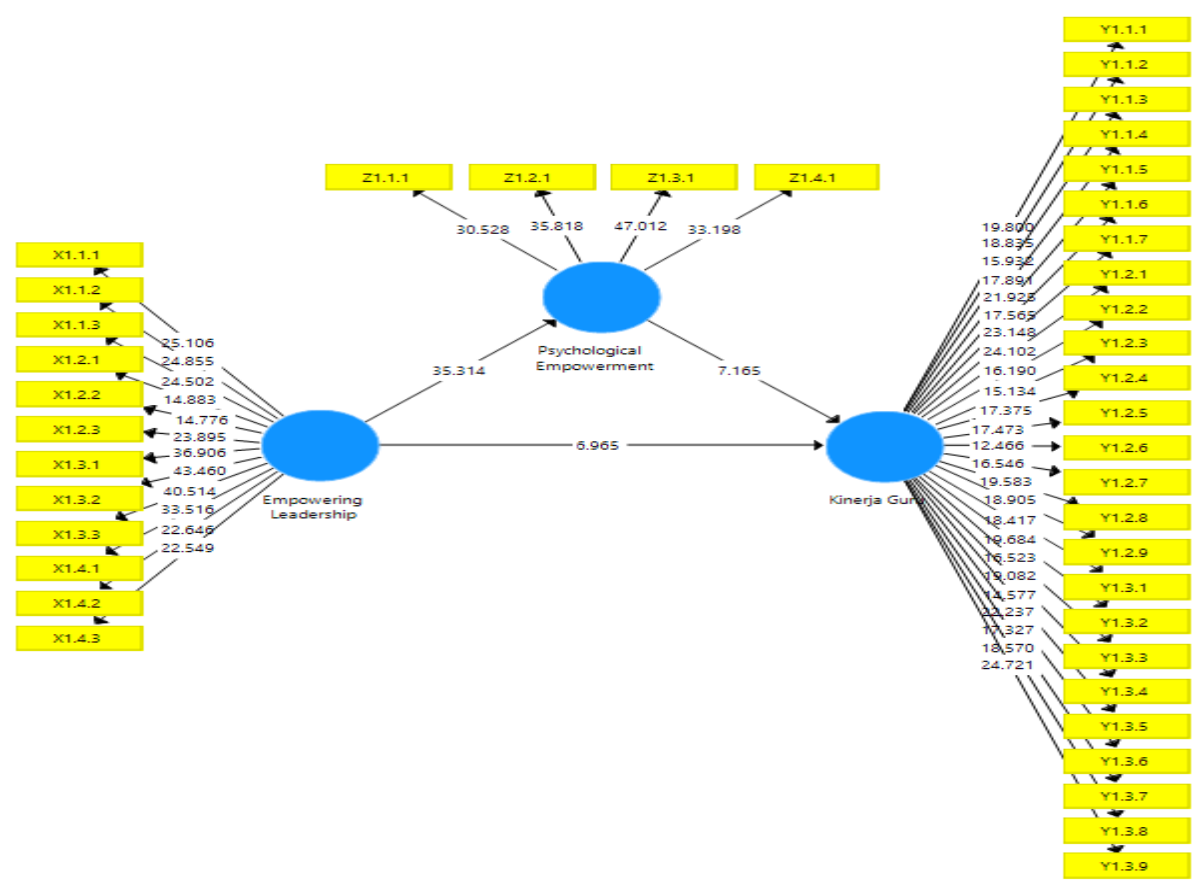

Sumber: Output SmartPLS 3.0 (2021, data diolah)

\section{Gambar 2. UJI MEASUREMENT MODEL}

Gambar 2. outer loadings setiap indikator memiliki angka yang melebihi 0,50, sehingga indikator setiap variabel adalah valid. Penelitian ini memiliki variabel dengan convergent validity yang baik.

Pada tabel 2. nilai composite reliability melebihi 0,70, sehingga, model variabel memiliki reliabilitas yang baik. Nilai cronbach's alpha lebih dari 0,60. Dengan demikian, seluruh konstruk model memiliki reliabilitas yang kuat. Nilai average variance extracted juga lebih besar dari 0,50. Oleh karenanya, seluruh model yang diuji telah memenuhi average variance extracted. 
Tabel 2.

COMPOSITE RELIABILITY, CRONBRACH'S ALPHA, AVE DAN R-SQUARE

\begin{tabular}{lcccc}
\hline \multicolumn{1}{c}{ Variabel } & $\begin{array}{c}\text { Composite } \\
\text { Reliability }\end{array}$ & Cronbach's Alpha & $\begin{array}{c}\text { Average Variance } \\
\text { Extracted }(\boldsymbol{A V E})\end{array}$ & $\boldsymbol{R}$-Square \\
\hline Empowering Leadership & 0,965 & 0,960 & 0,697 & 0,794 \\
Psychological Empowerment & 0,937 & 0,910 & 0,627 & 0,903 \\
Kinerja Guru & 0,977 & 0,975 & 0,788 & \\
\hline
\end{tabular}

Sumber: Output Smart PLS 3.0 (2021, data diolah)

Nilai R-Square pengaruh empowering leadership terhadap psychological empowerment yaitu sebesar 0,794, maka variabel independen empowering leadership mampu menjelaskan variabel konstruk psychological empowerment sebanyak 79,4\%, variabel lain yang tidak disebutkan oleh penelitian ini dapat menerangkan psychological empowerment pada SMP Negeri di Kecamatan Pacitan sejumlah 20,6\%. Nilai R-Square pengaruh empowering leadership terhadap variabel kinerja guru yaitu sebanyak 0,903, artinya variabel empowering leadership bisa menjelaskan variabel konstruk kinerja guru sebesar 90,3\%, sedangkan sisanya sebesar 9,7\%.dipengaruhi variabel lain di luar penelitian ini.

Tabel 3.

\section{PENGARUH LANGSUNG DAN TIDAK LANGSUNG}

\begin{tabular}{lccc}
\hline \multicolumn{1}{c}{ Variabel } & Original Sample & T-Statistics & Keterangan \\
\hline Empowering Leadership $\rightarrow$ Kinerja Guru & 0,486 & 6,965 & Hipotesis Diterima \\
Empowering Leadership $\rightarrow \quad$ Psychological & 0,891 & 35,314 & Hipotesis Diterima \\
Empowerment & 0,491 & 7,165 & Hipotesis Diterima \\
Psychological Empowerment $\rightarrow$ Kinerja Guru & 0,438 & 6,793 & Hipotesis Diterima \\
Empowering Leadership $\rightarrow$ Psychological & &
\end{tabular}

Sumber: Output Smart PLS 3.0 (2021, data diolah)

Tabel 3. dampak empowering leadership terhadap kinerja guru memiliki nilai $t$-statistics sebesar $6,965>1,96$. Hal tersebut menjelaskan bahwa terdapat pengaruh signifikan pada variabel empowering leadership terhadap kinerja guru. Nilai koefisien estimate sejumlah 0,486 memiliki tanda positif yang berarti apabila semakin tinggi empowering leadership maka kinerja guru juga akan semakin tinggi, begitupun sebaliknya.

Pengaruh empowering leadership terhadap psychological empowerment dengan $t$-statistics sebesar 35,314> 1,96. Data tersebut menjelaskan terdapat signifikansi pengaruh antara variabel empowering leadership dan psychological empowerment. Koefisien estimate sebesar 0,891 bertanda positif yang memiliki makna semakin tinggi empowering leadership maka akan semakin tinggi pula psychological empowerment, begitupun sebaliknya.

Dampak psychological empowerment terhadap kinerja guru besarnya nilai $t$-statistics adalah 7,165 > 1,96. Hal tersebut menjelaskan pengaruh signifikan antara variabel psychological empowerment dengan kinerja guru. Nilai koefisien estimate yakni 0,491 yang bertanda positif yang memiliki makna apabila semakin tinggi psychological empowerment maka kinerja guru akan meningkat, begitupun sebaliknya.

\section{Pengaruh Empowering Leadership terhadap Kinerja Guru}

Hasil pengujian menunjukkan empowering leadership berpengaruh signifikan terhadap kinerja guru. Penelitian ini memerkuat penelitian Ali et al. (2018) bahwa empowering leadership memiliki pengaruh signifikan terhadap employee performance. Apabila dikaitkan dengan penelitian yang dilakukan pada SMP Negeri di Kecamatan Pacitan, empowering leadership yang diterapkan kepala sekolah memengaruhi kinerja guru. Berdasarkan hasil wawancara dengan guru SMP Negeri di Kecamatan Pacitan, selama ini kepala sekolah telah mengikutsertakan semua guru dalam pengambilan 
Yustita Damayanti. Pengaruh Empowering Leadership terhadap Kinerja Guru dengan Psychological Empowerment sebagai Variabel Mediasi.

keputusan strategis sekolah yang biasanya dilaksanakan dalam rapat rutin antara kepala sekolah dengan semua guru.

Kepala sekolah memberikan informasi yang jelas kepada guru dalam mencapai visi dan misi. Semua guru dapat berkontribusi untuk mewujudkan visi dan misi tersebut. Setiap rapat mingguan kepala sekolah selalu mengingatkan target pencapaian visi dan misi, mengecek sejauh mana misi sudah dilaksanakan dan bagaimana perkembangan pencapaian visi sekolah. Pemasangan banner berisi visi dan misi juga dilaksanakan, agar guru maupun semua warga sekolah memahami, mengingat dan bersama-sama mewujudkan visi dan misi tersebut.

Upaya yang dilakukan kepala sekolah dalam memotivasi guru secara intrinsik diterima dengan baik oleh guru. Selama masa pandemi covid-19, kegiatan belajar mengajar dilaksanakan secara daring (dalam jaringan). Kepala sekolah memberikan pelatihan sistem pembelajaran daring untuk membantu guru agar dapat menyesuaikan dengan situasi saat ini. Kesempatan yang diberikan kepala sekolah tersebut memotivasi guru untuk memerbaiki kekurangan dalam model pembelajaran mereka, yang kemudian berdampak baik terhadap kinerja.

Penerapan kegiatan pembelajaran daring sudah terlaksana selama satu tahun. Guru SMP Negeri di Kecamatan Pacitan sudah memiliki model pembelajaran masing-masing sesuai inovasi mereka. Salah satunya dengan memanfaatkan media aplikasi pembelajaran. Bantuan kuota internet yang disediakan pemerintah untuk menunjang pembelajaran secara online sangat membantu bagi siswa. Namun, ada beberapa siswa yang tempat tinggalnya berada pada lokasi yang belum tersedia jaringan internet secara penuh. Sehingga hal tersebut menghambat siswa dalam memahami materi pembelajaran. Dengan demikian, empowering leadership yang diterapkan kepala sekolah berpengaruh secara signifikan positif terhadap kinerja guru SMP Negeri di Kecamatan Pacitan.

\section{Pengaruh Empowering Leadership terhadap Psychological Empowerment}

Hasil pengujian diketahui bahwa empowering leadership memiliki pengaruh signifikan terhadap psychological empowerment. Hal ini mendukung penelitian Zhang \& Bartol (2010). Hasil wawancara dengan guru SMP Negeri di Kecamatan Pacitan, empowering leadership yang diterapkan kepala sekolah memberikan dampak baik terhadap psychological empowerment guru. Kepercayaan dan kesempatan untuk melaksanakan pekerjaan sesuai dengan keahlian, mengikutsertakan dalam pengambilan keputusan dan memberikan arahan dalam memahami pentingnya pekerjaan bagi efektivitas sekolah secara keseluruhan yang dilakukan kepala sekolah memotivasi guru untuk terus menunjukkan kinerja yang baik.

Penerapan empowering leadership yang dilakukan kepala sekolah sudah baik, tetapi ada beberapa hal yang perlu diperbaiki. Misalnya, dalam pemberian pekerjaan atau jabatan tertentu diluar tanggung jawab sebagai pendidik kepada seorang guru, terkadang kepala sekolah tidak memberikan informasi yang jelas terkait alasan guru tersebut terpilih, sehingga menimbulkan menurunnya motivasi dari guru yang lain untuk meningkatkan kinerjanya. Dari penjelasan di atas, empowering leadership berpengaruh signifikan positif terhadap psychological empowerment.

\section{Pengaruh Psychological Empowerment terhadap Kinerja Guru}

Hasil pengujian mengungkapkan bahwa psychological empowerment memiliki pengaruh terhadap kinerja guru. Penelitian ini mendukung hasil penelitian Adriansyah \& Suryani (2018). Hasil wawancara dengan guru SMP Negeri di Kecamatan Pacitan menjelaskan bahwa adanya psychological empowerment yang dirasakan guru menghasilkan kemandirian dan motivasi intrinsik pada setiap individu yang pada gilirannya membawa dampak positif terhadap kinerja. Guru memiliki psychological empowerment yang baik dalam melaksanakan tanggung jawabnya sebagai pendidik. Meskipun dalam hal kedisiplinan masih belum maksimal. Pada masa pandemi, ketertiban kehadiran beberapa guru masih kurang. Salah satu penyebabnya karena perubahan sistem absensi yang tidak lagi menggunakan teknologi fingerprint dan adanya penerapan sistem masuk kerja bergiliran. Dari penjelasan di atas, psychological empowerment yang dirasakan guru SMP Negeri di Kecamatan Pacitan berpengaruh signifikan positif terhadap kinerja guru. 
Pengaruh Empowering Leadership terhadap Kinerja Guru dengan Psychological Empowerment sebagai Variabel Mediasi

Hasil dari pengujian memerlihatkan psychological empowerment memediasi pengaruh antara empowering leadership terhadap kinerja guru. Penelitian ini memerkuat hasil penelitian Gahlawat et al. (2018). Berdasarkan hasil wawancara pada guru SMP Negeri di Kecamatan Pacitan, ketika kepala sekolah menerapkan empowering leadership dalam memimpin, semua guru merasakan psychological empowerment yang tinggi, yang kemudian dapat meningkatkan kinerja mereka. Misalnya, SMP Negeri di Kecamatan Pacitan akan mengikuti kompetisi tingkat provinsi. Dalam mempersiapkan calon peserta, kepala sekolah menerapkan empowering leadership dengan memberikan kewenangan kepada beberapa guru untuk menjadi pembimbing calon peserta. Adanya tanggung jawab dan kepercayaan yang diberikan kepala sekolah mampu memotivasi guru untuk menghasilkan kinerja yang baik. Pada saat pemberian tanggung jawab, kepala sekolah juga menjelaskan terkait deskripsi kerja guru, sehingga dalam pelaksanaan pembimbingan berjalan lancar. Proses pembimbingan yang baik akan menghantarkan hasil kompetisi yang baik pula, hal ini berdampak pada semakin baiknya kinerja guru tersebut. Dari pernyataan tersebut, dapat dinyatakan bahwa terdapat pengaruh signifikan positif empowering leadership terhadap kinerja guru yang dimediasi oleh psychological empowerment.

\section{KESIMPULAN}

Empowering leadership terbukti berpengaruh signifikan positif terhadap kinerja guru, empowering leadership berpengaruh signifikan positif terhadap psychological empowerment dan psychological empowerment berpengaruh signifikan positif terhadap kinerja guru serta psychological empowerment sebagai variabel mediasi memengaruhi hubungan antara empowering leadership dengan kinerja guru.

Penelitian ini memberikan saran praktis yang bersumber dari analisis dan hasil wawancara yakni menyarankan kepada kepala sekolah untuk meningkatkan keefektifan penerapan empowering leadership dengan memberikan informasi yang jelas terkait alasan seorang guru terpilih menduduki jabatan dan menerima pekerjaan tertentu diluar tanggung jawab sebagai pendidik, sehingga guru yang lain dapat termotivasi untuk meningkatkan kinerjanya. Selain itu, untuk meningkatkan kedisiplinan kehadiran guru kepala sekolah perlu menerapkan disiplin yang tegas. Pemberian sanksi perlu dilakukan agar guru tidak melakukan kesalahan yang sama. Bentuknya bisa berupa sanksi ringan, sedang maupun berat. Untuk memotivasi guru guna menjaga dan meningkatkan kedisiplinannya, perlu adanya pemberian reward bagi mereka. Reward ini dapat berupa pemberian penghargaan secara materil maupun non materil.

Penelitian ini juga memberikan rekomendasi kepada pemerintah daerah untuk meningkatkan penyediaan infrastruktur jaringan internet sampai ke pelosok desa. Pemberlakuan kebijakan pembelajaran secara daring menuntut siswa untuk menggunakan teknologi berbasis jaringan internet. Wilayah tempat tinggal beberapa siswa yang belum tersedia jaringan secara penuh menghambat aktivitas belajar mereka. Sehingga dengan adanya ketersediaan infrastruktur tersebut akan mempermudah kegiatan belajar mengajar siswa. Penelitian selanjutnya dapat meneliti variabel disiplin kerja, dan variabel ketersediaan infrastruktur penunjang pembelajaran.

\section{DAFTAR PUSTAKA}

Adriansyah, \& Suryani, A. I. (2018). Pengaruh Pemberdayaan Psikologis terhadap Kinerja Karyawan dengan Perilaku Kewargaan Organisasi sebagai Variabel Mediasi pada Karyawan PT. Telkom Witel Aceh. Jurnal Ilmiah Mahasiswa Ekonomi Manajemen, 3(4), 1-15. https://doi.org/10.24815/jimen.v3i4.7149

Aguinis, H. (2007). Performance Management (3rd ed.). United States of America: Prentice Hall.

Ahearne, M., Mathieu, J., \& Rapp, A. (2005). To Empower or Not to Empower Your Sales Force? An Empirical Examination of the Influence of Leadership Empowerment Behavior on 
Yustita Damayanti. Pengaruh Empowering Leadership terhadap Kinerja Guru dengan Psychological Empowerment sebagai Variabel Mediasi.

Customer Satisfaction and Performance. Journal of Applied Psychology, 90(5), 945-955. https://doi.org/10.1037/0021-9010.90.5.945

Albrecht, S. L., \& Andreetta, M. (2011). The Influence of Empowering Leadership, Empowerment and Engagement on Affective Commitment and Turnover Intentions in Community Health Service Workers: Test of a Model. Leadership in Health Services, 24(3), 228-237. https://doi.org/10.1108/17511871111151126

Ali, M., Rahman, M. A., Lei, S., \& Jie, Z. S. (2018). Empowering Leadership and Employee Performance : a Mediating Role of Thriving at Work. International Journal of Asian Business and Information Management, 9(2), 1-14. https://doi.org/10.4018/IJABIM.2018040101

Amundsen, S., \& Martinsen, Ø. L. (2015). Linking Empowering Leadership to Job Satisfaction , Work Effort, and Creativity: The Role of Self-Leadership and Psychological Empowerment. Journal of Leadership \& Organizational Studies, 22(3), 304-323. https://doi.org/10.1177/1548051814565819

Arnold, J., Arad, S., Rhoades, J., \& Drasgow, F. (2000). The Empowering Leadership Questionnaire: The Construction and Validation of a New Scale for Measuring Leader Behaviors. Journal of Organizational Behavior, 21, 249-469. https://doi.org/10.1002/(SICI)1099-1379(200005)21

Atik, S., \& Celik, O. T. (2020). An Investigation of the Relationship between School Principals' Empowering Leadership Style and Teachers' Job Satisfaction: The Role of Trust and Psychological Empowerment. International Online Journal of Educational Science, 12(3), 177-193. https://doi.org/10.15345/iojes.2020.03.014

Campbell, J. K., \& Hwa, Y. S. (2014). Workplace Spirituality and Organizational Commitment Influence on Job Performance among Academic Staff. Jurnal Pengurusan, 40, 115-123. https://doi.org/10.17576/PENGURUSAN-2014-40-10

Cetin, F., \& Askun, D. (2018). The Effect of Occupational Self-efficacy on Work Performance Through Intrinsic Work Motivation. Management Research Review, 41(3), 1-16. https://doi.org/10.1108/MRR-03-2017-0062

Chasanah, N. (2008). Analisis Pengaruh Empowerment, Self Efficacy dan Budaya Organisasi terhadap Kepuasan Kerja dalam Meningkatkan Kinerja Karyawan. Jurnal Penelitian Ekonomi dan Bisnis, 3(1), 39-47.

Chen, G., Sharma, P. N., Edinger, S. K., \& Shapiro, D. L. (2011). Motivating and Demotivating Forces in Teams: Cross-Level Influences of Empowering Leadership and Relationship Conflict. Journal of Applied Psychology, 96(3), 541-557. https://doi.org/10.1037/a0021886

Fong, K. H., \& Snape, E. (2015). Empowering Leadership, Psychological Empowerment and Employee Outcomes : Testing a Multi-level Mediating Model. British Journal of Management, 26(1), 126-138. https://doi.org/10.1111/1467-8551.12048

Gahlawat, N., Kundu, S. C., \& Kumar, S. (2019). Empowering Leadership and Job Performance: Mediating Role of Psychological Empowerment. Management Research Review, 42(5), 605624. https://doi.org/10.1108/MRR-04-2018-0183

Goodman, S. A., \& Svyantek, D. J. (1999). Person - Organization Fit and Contextual Performance : Do Shared Values Matter. Journal of Vocational Behavior, 55(2), 254-275. https://doi.org/001$8791 / 99$

Hameed, A., \& Waheed, A. (2015). Impact of Psychological Empowerment on Employee's 
Performance. Pakistan Journal of Humanities and Social Sciences, 3(1), 1-5. https://doi.org/10.52131/pjhss.2015.0301.0008

Hartanto, S., \& Purwanto, S. (2019). Supervisi dan Penilaian Kinerja Guru (MPPKS-PKG). Jakarta: Direktorat Jenderal Guru dan Tenaga Kependidikan.

Humborstad, S. I. W., Nerstad, C. G. L., \& Dysvik, A. (2014). Empowering leadership , employee goal orientations and work performance A competing hypothesis approach. Personnel Review, 43(2), 246-271. https://doi.org/10.1108/PR-01-2012-0008

Kasemsap, K. (2013). Strategic Business Management: A Practical Framework and Causal Model of Empowering Leadership, Team Cohesion, Knowledge-Sharing Behavior, and Team Performance. Journal of Social and Development Sciences, 4(3), 100-106. https://doi.org/10.22610/jsds.v4i3.740

Kazlauskaite, R., Buciuniene, I., \& Turauskas, L. (2011). Organisational and Psychological Empowerment in the HRM-Performance Linkage. Employee Relations, 34(2). https://doi.org/10.1108/01425451211191869

Kim, M., \& Beehr, T. A. (2018). The International Journal of Human Resource Empowering leadership : leading people to be present through affective organizational commitment? The International Journal of Human Resource Management, 31(16), 1-25. https://doi.org/10.1080/09585192.2018.1424017

Knezovic, E., \& Musrati, M. A. (2018). Empowering Leadership, Psychological Empowerment and Employees' Creativity: A gender perspective. International Journal of Innovation, Creativity and Change, 4(2), 51-72.

Liden, R. C., Wayne, S. J., \& Sparrowe, R. T. (2000). An Examination of the Mediating Role of Psychological Empowerment on the Relations Between the Job, Interpersonal Relationships, and Work Outcomes. Journal of Applied Psychology, 85(3), 407-416. https://doi.org/10.1037//0021-9010.85.3.407

Marliani, R. (2015). Psikologi Industri \& Organisasi. Bandung: Pustaka Setia.

Muliawan, Y., Perizade, B., \& Cahyadi, A. (2017). Pengaruh Keterikatan Karyawan (Employee Engagement) terhadap Kinerja Karyawan di PT Badja Baru Palembang. Jurnal Ilmiah Manajemen Bisnis dan Terapan, 14(2), 69-78. https://doi.org/10.29259/jmbt.v14i2.5293

Özaralli, N. (2015). Linking Empowering Leader to Creativity: The Moderating Role of Psychological ( Felt ) Empowerment. Procedia - Social and Behavioral Sciences, 181, 366376. https://doi.org/10.1016/j.sbspro.2015.04.899

Park, J., \& Hassan, S. (2018). Does the Influence of Empowering Leadership Trickle Down? Evidence From Law Enforcement Organizations. Journal of Public Administration Research and Theory, 28(2), 212-225. https://doi.org/10.1093/jopart/mux047

Pearce, C. L., \& Sims, H. P. (2002). Vertical Versus Shared Leadership as Predictors of the Effectiveness of Change Management Teams: An Examination of Aversive, Directive, Transactional, Transformational, and Empowering Leader Behaviors. Group Dynamics Theory Research and Practice, 6(2), 172-197. https://doi.org/10.1037/1089-2699.6.2.172

Raub, S., \& Robbert, C. (2010). Differential Effects of Empowering Leadership on In-role and Extrarole Employee Behaviors: Exploring the Role of Psychological Empowerment and Power Values. Human Relations, 63(11), 1743-1770. https://doi.org/10.1177/0018726710365092 
Yustita Damayanti. Pengaruh Empowering Leadership terhadap Kinerja Guru dengan Psychological Empowerment sebagai Variabel Mediasi.

Rayan, A. R. M., Sebaie, A. S. M., \& Ahmed, N. A. (2019). Empowering Leadership Behavior and Work Engagement: The Mediating Role of Psychological Empowerment. Current Perspective to Economics and Management, 3(12), 27-43. https://doi.org/10.9734/bpi/cpem/v3

Rochani, A. G. S., \& Wijayati, D. T. (2020). Empowering Leadership, Kreativitas Karyawan, dan Creative Self Efficacy (Studi pada Bank Jatim Kantor Cabang Trenggalek). Jurnal Ilmu Manajemen, 8(1), 1-8.

Sampurno, D., \& Wibowo, A. (2015). Kepemimpinan Kepala Sekolah, Lingkungan Kerja, Motivasi Kerja dan Kinerja Guru di SMK Negeri 4 Pandeglang. Jurnal Pendidikan Ekonomi Dan Bisnis, 3(2), 165-180. https://doi.org/10.21009/JPEB

Spreitzer, G. M. (1995). Psychological Empowerment in The Workplace: Dimensions, Measurement, and Validation. Academy of Management Journal, 38(5), 1442-1465. https://doi.org/10.5465/256865

Srivastava, A., Bartol, K. M., \& Locke, E. A. (2006). Empowering Leadership in Management Teams: Effects on Knowledge Sharing, Efficacy and Performance. The Academy of Management Journal, 49(6), 1239-1251. https://doi.org/10.2307/20159830

Sudibjo, N., \& Widiastuti, A. (2021). The Effects of Empowering Leadership , Job Crafting , and Well-Being on Job Performance. Educational Managements, 10(1), 67-75. http://journal.unnes.ac.id/sju/index.php/eduman

Supratikto, A., Supriyanto, E., \& Fathoni, A. (2014). Supervisi Akademik di SMP Negeri 4 Pacitan. Jurnal Manajemen Pendidikan, 9(2), 141-149.

Tanriverdi, H., Turan, S., \& Yimaz, A. (2019). The Effect of Psychological Empowerment on Work Life Quality. The European Proceeding of Social \& Behavioural Sciences, 13, 152-162. https://doi.org/10.15405/epsbs.2019.12.03.13

Thomas, D., \& Rahschulte, T. (2018). The Moderating Effects of Power Distance and Individualism / Collectivism on Empowering Leadership , Psychological Empowerment , and Self- Leadership in International Development Organizations. International Leadership Journal, 10(3), 3-39. https://digitalcommons.georgefox.edu/gfsb

Undang-undang Republik Indonesia Nomor 20 Tahun 2003 Tentang Sistem Pendidikan Nasional, (2003).

Wallace, C., Johnson, P., Mathe, K., \& Paul, J. (2011). Structural and Psychological Empowerment Climates, Performance, and the Moderating Role of Shared Felt Accountability: A Managerial Perspective. Journal of Applied Psychology, 96(4), 840-850. https://doi.org/10.1037/a0022227

Wardani, L. M. I., \& Amaliah, A. (2020). The Role of Psychological Empowerment as Mediator between Psychological Capital and Employee Well-being. Journal of Critical Reviews, 7(13), 291-296. https://doi.org/10.31838/jcr.07.13.49

Welbourne, T. M., Johnson, D. M., \& Erez, A. (1997). The Role-Based Performance Scale: Validity Analysis of a Theory-Based Measure. In CAHRS Working Paper Series (Issue 5). https://doi.org/10.2307/256941

Yilmaz, O. D. (2015). Revisiting the Impact of Perceived Empowerment on Job Performance: Results from Front-Line Employees. TURIZAM, 19(1), 34-46. https://doi.org/10.5937/Turizam1501034Y 
Yusoff, R. Bin, Ali, A., \& Khan, A. (2014). Assessing Reliability and Validity of Job Performance Scale among University Teachers. Journal of Basic and Applied Scientific Research, 4(1), 3541.

Zhang, \& Bartol, K. M. (2010). Linking Empowering Leadership and Employee Creativity: The Influence of Psychological Empowerment, Intrinsic Motivation, and Creative Process Engagement. Academy of Management Journal, 53(1), 107-128. https://doi.org/10.5465/AMJ.2010.48037118

Zhang, P., \& Gheibi, S. (2015). The Impact of Empowering Leadership on Work Performance and Work Family Conflict: The Role of Gender. European Scientific Journal, 11(11), 367-379. https://eujournal.org/index.php/esj/article/view/5526

Zhu, J., Yao, J., \& Zhang, L. (2019). Linking Empowering Leadership to Innovative Behavior in Professional Learning Communities: the Role of Psychological Empowerment and Team Psychological Safety. Asia Pacific Education Review, 12(2), 1-15. https://doi.org/10.1007/s12564-019-09584-2 